\title{
Peran Kelompok Usaha Wisata dalam Penyediaan Fasilitas Wisata di Desa Colo, Kabupaten Kudus
}

\author{
Role of Tourism Group in Colo Village to Provide \\ Tourism Facilities in Kudus Regency
}

Deny Aditya Puspasari

Info Artikel

Diterima : 2 Mei 2021

Direvisi : 25 Mei 2021

Disetujui : 8 Juni 2021

Kata kunci:

Fasilitas

Kelompok Wisata

Pariwisata

Keywords:

Facilities

Tourism

Tourism Group

Corresponding Author:

Deny Aditya Puspasari

Denyadityapuspasari@lecturer.undip.ac.id 082220589742
Sekolah Vokasi Universitas Diponegoto

\begin{tabular}{l} 
Abstrak \\
\hline Pariwisata menjadi salah satu sektor pada bidang \\
ekonomi, yang berperan penting dalam pengentasan \\
kemiskinan wilayah. Sarana dan prasarana menjadi \\
salah satu faktor pendukung dalam pengembangan \\
pariwisata, dengan begitu kegiatan pariwisata dapat \\
berjalan dengan baik. Desa Wisata Colo, yang terletak \\
di kawasan Pegunungan Muria, merupakan salah satu \\
destinasi wisata yang terus berkembang. Melihat \\
potensi ini, masyarakat Desa Colo telah melakukan \\
pengelolaan obyek wisata secara swadaya dan \\
informal melalui pembentukan kelompok usaha wisata \\
dan komunitas wisata, seperti ojek, pengusaha \\
penginapan dan pedagang kaki lima. Tujuan dari \\
penelitian ini yaitu mengidentifikasi peran kelompok \\
usaha tersebut dalam menyediakan sarana dan \\
prasarana dalam mendukung kegiatan pariwisata di \\
Desa Colo. Data mengenai peran tersebut didapatkan \\
dari institusi pemerintah Kabupaten Kudus serta \\
wawancara dengan pelaku kelompok wisata tersebut. \\
Hasil dari kajian ini memperlihatkan adanya peran \\
dari kelompok wisata yang sangat penting dalam \\
menyediakan fasilitas pendukung kegiatan wisata, \\
sehingga dapat mendorong kunjungan para wisatawan \\
ke obyek wisata yang disediakan di Desa Colo
\end{tabular}

Abstract

The tourism is one of economic sector, which plays an important role to reduce poverty in a region. Tourism infrastructure become the supporting factors in tourism development, so that the tourism activities can run well. The location of Colo tourim village is in the Muria Mountains, which is the one of potential tourist destinations. Regarding to this potency, the community manages tourism objects independently and informally, such as motorcycle taxis, lodging entrepreneurs, and street vendors. The purpose of this study is to identify the role of these business groups in providing facilities and infrastructure to support tourism activities in Colo Village. The Datas were obtained from the Kudus Regency government institution, and also interviews with the tourism group actors. The results of this study shows that the The tourism groups has a very important role in providing the facilities for tourism activities, so that the tourists will be encouraged to come to the tours provided in Colo Village 


\section{PENDAHULUAN}

Desa Colo merupakan jalur masuk utama dari wisata religi ziarah Sunan Muria di Kabupaten Kudus yang memberikan kontribusi pada peningkatan jumlah wisatawan di kawasan tersebut. Berdasarkan data jumlah pengunjung wisata di Kabupaten Kudus, sebanyak $80 \%$ wisatawan merupakan pengunjung dari wisata religi Sunan Muria. Data dari Badan Pusat Statistik Kabupaten Kudus menyatakan pada tahun 2012 jumlah wisatawan sebanyak 563.900 orang, tahun 2013 sebanyak 719.486 orang, dan tahun 2014 sebanyak 740.262 orang.

Peningkatan jumlah wisatawan tersebut membuat masyarakat Desa Colo berinisiatif untuk mengembangkan atraksi wisata. Tujuan pengembangan atraksi wisata adalah sebagai penarik, pemikat, dan perangsang minat wisata yang nantinya akan mempengaruhi pemilihan tujuan wisata, penyedia kepuasan bagi wisatawan serta penyedia manfaat dari kegiatan wisata (Gunn, 2002). Jenis aktivitas baru yang dikembangkan di kawasan Desa Wisata Colo adalah agrowisata kebun kopi, outbond, dan wisata edukasi membuat batik khas Kudus. Adanya inisiatif masyarakat dalam mengembangkan atraksi wisata tersebut membuat pemerintah melegalkan kawasan tersebut menjadi Desa Wisata pada tahun 2013 melalui Keputusan Kepala Dinas Kebudayaan dan Pariwisata Kabupaten Kudus No.556 / 23.01 / 043C / 2014 (Puspasari \& Sariffuddin, 2015).

Pada penelitian sebelumnya (Puspasari, 2015) menunjukkan bahwa kegiatan wisata yang ada di Desa Colo berdampak pada peningkatan kesejahteraan masyarakat secara ekonomi. Aspek ekonomi tersebut meliputi perubahan mata pencaharian, meningkatnya peran gender untuk mendukung aktivitas wisata, dan adanya peningkatan pendapatan masyarakat sekitarnya. Perbedaan penelitian ini dengan penelitian sebelumnya adalah pembahasan peran kelompok wisata tersebut untuk mendukung kegiatan pariwisata.

Selain aspek ekonomi, dampak perkembangan pariwisata yang dirasakan adalah perubahan pada aspek lingkungan. Perubahan aspek lingkungan ini antara lain perubahan lahan, pengembangan infrastruktur, serta perubahan fungsi lahan yang diakibatkan adanya aktivitas pariwisata (Yürüdür and Dicle, 2011). Aktivitas pariwisata berdampak pada kebutuhan ruang untuk akomodasi pendukung aktivitas pariwisata (Lakshmi and Shaji, 2016). Untuk memenuhi kebutuhan fasilitas pendukung aktivitas wisata, masyarakat setempat berinisiatif membangun warung makan, toko kelontong, penginapan, persewaan toilet, dan tempat parkir pada lahan baru milik warga atau melakukan penambahan pada rumah tinggal mereka.

CBT (Community Based Tourism) mulai berkembang pada sekitar dasawarsa 1970-an, yang diawali dari adanya kesadaran untuk mengurangi dampak negatif dari pariwisata massal, serta kebangkitan gerakan konservasi alam (Siri \& Chantraprayoon, 2017). Inisiatif pariwisata ini kemudian dikenal luas, dan selanjutnya terus dikembangkan karena menjadi salah satu strategi untuk mempromosikan pariwisata berkelanjutan (Wijaya \& Hutama 2020). Metode CBT terbukti memberikan beberapa manfaat, khususnya dalam kegiatan wisata, di mana wisatawan dapat belajar tentang budaya dan sumber daya masyarakat, serta memberikan peningkatan pendapatan pariwisata bagi masyarakat. Partisipasi masyarakat adalah salah satu dari banyak faktor kunci yang berkontribusi terhadap keberhasilan pariwisata berbasis masyarakat (Supriharjo dkk, 2016). Peran kelompok wisata lokal menjadi salah satu bentuk CBT yang diaplikasikan oleh masyarakat di Desa Colo, Kabupaten Kudus, untuk meningkatkan pendapatan masyarakat, khususnya di bidang pariwisata.

\section{METODE}

Identifikasi peran kelompok wisata yang dilakukan di Desa Colo, Kudus merupakan penelitian dengan tema pariwisata. Komponen pendukung kegiatan pariwisata antara lain atraksi, amenitas, 
akomodasi/fasilitas dan aksesbilitas. Metode yang digunakan dalam penelitian ini adalah mixed-method, di mana data sekunder didapatkan dari telaah dokumen terkait kepariwisataan, sedangkan data primer didapatkan melalui proses wawancara mendalam dari kelompok wisata tersebut. Data yang dibutuhkan meliputi isu pengembangan wisata, faktor pendukung pengembangan wisata, serta identifikasi stakeholder dalam pengembangan wisata yang ada di Desa Wisata Colo Kabupaten Kudus.

\section{HASIL DAN PEMBAHASAN}

\section{Atraksi Wisata di Desa Colo}

Terdapat tiga jenis aktivitas wisata di Desa Wisata. Aktivitas tersebut meliputi aktivitas wisata religi dan aktivitas wisata alam. Potensi utama wisata yang terdapat di Desa Wisata Colo adalah aktivitas wisata religi.

Pada aktivitas wisata religi, daya tarik yang ditawarkan kepada wisatawan adalah atraksi wisata religi. Ada 3 jenis atraksi wisata religi di Desa Wisata Colo, antara lain makam Sunan Muria, Buka Luwur, dan Parade Seribu Kupat. Buka Luwur Sunan Muria merupakan tradisi ritual yang masih banyak dilestarikan oleh masyarakat Kudus, khususnya warga Desa Colo. Upacara tradisi ini dilakukan untuk mengirim doa dan mendapat berkah dari Sunan Muria. Buka Luwur Sunan Muria dilaksanakan pada tanggal 14-15 Sura. Sedangkan pada budaya Parade Seribu Kupat dilaksanakan oleh masyarakat untuk memperingati 7 hari bulan Syawal, di mana tradisi ini dilakukan oleh Walisongo untuk memasukkan ajaran islam.

Pada aktivitas wisata alam, atraksi yang ditawarkan adalah keindahan alam dan edukasi lingkungan yang terdapat di Desa Wisata Colo, antara lain Air Terjun Monthel, Wisata Alam/Ecotourism, sumber air tiga rasa dan air terjun Gonggomino. Selain atraksi tersebut, atraksi lain yang mulai dikembangkan yaitu agrowisata kebun kopi dan outbound. Jenis aktivitas selanjutnya yaitu wisata edukasi, yang bertujuan untuk

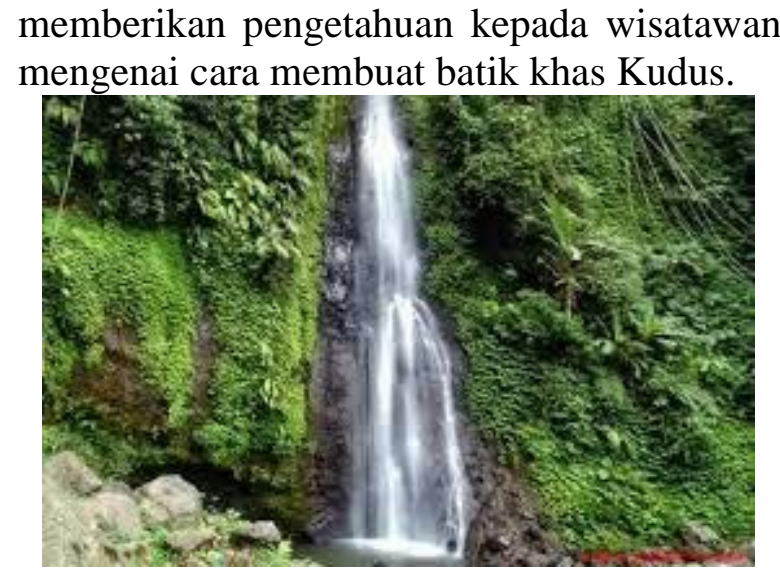

Gambar 1. Daya Tarik Wisata Alam

Sumber: Obsevasi Peneliti, 2020

\section{Kelompok Wisata di Desa Colo}

Terdapat 6 kelompok wisata yang berkembang di Desa Colo, yakni Kelompok Penjual Accessories, Kelompok Ojek, Kelompok Pedagang (Warung/Toko), Kelompok persewaan toilet, Kelompok Tour Guide (Pemandu Wisata) dan Kelompok usaha Penginapan. Pada konteks pengembangan fasilitas pendukung wisata kelompok, yang paling banyak berperan antara lain Kelompok Pedagang (Warung/Toko), Kelompok Ojek, Kelompok Persewaan Toilet dan Kelompok Usaha Penginapan. Kelompok usaha ini banyak berkembang secara swadaya karena kurangnya ketersediaan sarana prasarana /fasilitas pendukung ini, bila dibandingkan dengan pertambahan jumlah wisatawan di Desa Colo.

Kelompok usaha Pedagang (Warung/Toko) di Desa Colo terdapat 53 unit usaha, baik warung kelontong maupun warung makan yang menyediakan kebutuhan makanan dan minuman bagi para wisatawan di Desa Colo. kelompok persewaan toilet menyediakan fasilitas toilet sebanyak 9 unit, yang tersebar di sekitar Terminal Wisata Colo atau tepatnya berada di RW 1 . Usaha ini, tidak hanya menyediakan kebutuhan toilet bagi para pengunjung, tetapi juga lahan parkir bagi pengunjung yang menggunakan kendaraan pribadi untuk berwisata di Desa Colo. 
Berdasarkan hasil survei lapangan, teridentifikasi Kelompok usaha ojek wisata yang ada di Desa Colo yaitu sebanyak 1.200 anggota yang tersebar secara merata. Kelompok ojek sendiri menjadi salah satu kelompok yang aktif memiliki kegiatan pertemuan rutin. Selain itu, kelompok ojek wisata ini telah berkontribusi dalam penyediaan transportasi menuju lokasi destinasi wisata yang sulit untuk dijangkau dengan menggunakan kendaraan besar. Hal ini dikarenakan kondisi lokasi menuju destinasi wisata memiliki kelerengan yang cukup terjal, sehingga akan sulit bagi pengunjung yang menggunakan kendaraan besar untuk menjangkau destinasi wisata tersebut.

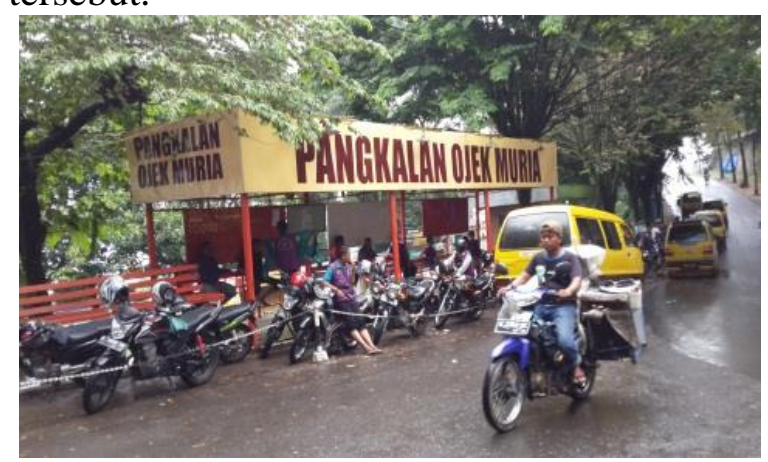

Gambar 2. Kelompok Ojek Wisata

Sumber: Obsevasi Peneliti, 2020

Kelompok penginapan memiliki jumlah anggota sebanyak 20 orang, yang menyediakan akomodasi wisata berupa penginapan. Biaya yang ditawarkan untuk menyewa penginapan tersebut yaitu dengan range harga sebesar $\mathrm{Rp}$. 300.000,-/malam. Pemasaran usaha ini dilakukan melalui biro perjalanan atau melalui sopir bus yang datang di terminal Colo, sehingga jika suatu hari biro perjalanan/supir tersebut membawa wisata-wan ke Desa Colo dapat menghubungi pemilik usaha penginapan tersebut. Fenomena yang banyak terjadi pada usaha akomodasi wisata, yaitu adanya tambahan usaha sampingan. Usaha sampingan tersebut adalah penjualan makanan ringan untuk para tamu yang menginap di penginapan mereka. Produksi makanan tersebut dilakukan pada bagian dapur di dalam penginapan.
Berdasarkan identifikasi di atas, dapat diketahui bahwa peningkatan jumlah wisatawan dan aktivitas wisata telah memberikan pengaruh terhadap tumbuhnya inisiatif masyarakat untuk berpartisipasi dalam aktivitas wisata yang ada di wilayahnya. Peranan partisipasi dibagi menjadi dua, yakni partisipasi vertikal dan horizontal (Ftiyani et al., 2018). Pada studi kasus yang terjadi di Desa Colo, bentuk partisipasi yang dilakukan adalah partisipasi horizontal, di mana masyarakat ikut serta aktif dalam kelompok yang ada di sekitarnya.

Proporsi perbandingan kelompok usaha yang ada di Desa Colo dapat dilihat pada Gambar 3. Gambar tersebut menunjukkan bahwa persentase terbesar kelompok usaha di Desa Colo adalah sektor transportasi, berupa ojek wisata. Fungsinya adalah untuk mengakomodir kebutuhan transportasi untuk menjangkau lokasi destinasi wisata secara mudah dan cepat.

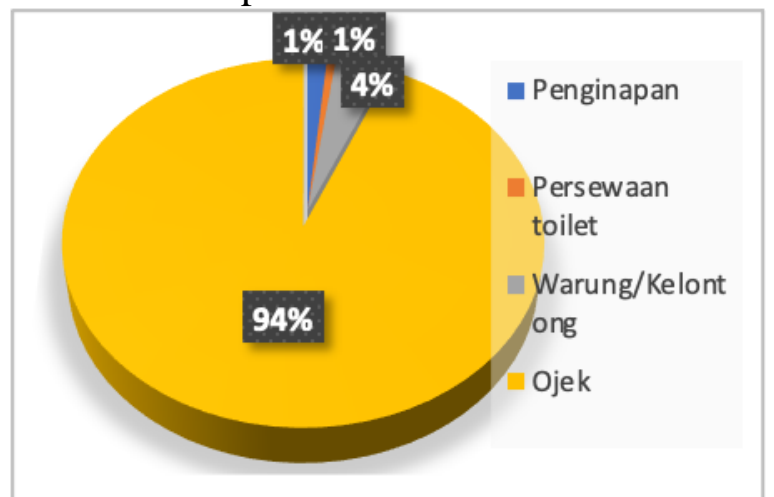

Gambar 3. Diagram Perbandingan Kelompok Wisata

Sumber: Analisis Peneliti, 2021

\section{Fasilitas Wisata di Desa Colo Kabupaten Kudus}

Fasilitas menjadi salah satu hal penting dalam mendukung aktivitas pariwisata. Penyediaan fasilitas yang ada di Desa Colo saat ini masih menjadi tanggung jawab penuh dari pemerintah Kabupaten Kudus, selaku pelaksana pengguna anggaran. Adapun fasilitas yang saat ini sudah dipenuhi oleh Pemerintah Kabupaten Kudus dapat dilihat pada Tabel 1. Berdasarkan tabel tersebut, dapat diketahui bahwa Community Based Tourism (CBT) telah banyak diterapkan oleh 
masyarakat yang ada di Desa Colo. Hal ini telah sesuai dengan pernyataan yang menyatakan bahwa peran masyarakat sangat penting, khususnya dalam peningkatan keberhasilan suatu aktivitas wisata di wilayahnya (Haryati et al., 2016). Hal ini dapat dilihat dari adanya inisiatif masyarakat untuk menyediakan fasilitas pendukung wisata dengan mempertimbangkan adanya peluang peningkatan aktivitas wisata.

\section{Peran Kelompok Wisata}

Kegiatan pariwisata berkaitan erat dengan kerjasama antar stakeholder, baik dari pemerintah, pihak swasta, maupun masyara-kat yang ada di Desa Colo. Salah satu upaya pengembangan aktivitas pariwisata adalah dengan mendorong masyarakat untuk berperan aktif, baik dalam hal pengambilan keputusan, maupun dalam hal lainnya (Raharjana, 2012). Peran Pemerintah Kabupaten sangatpenting dalam membangun hubungan yang harmonis antara pihak swasta maupun masyarakat untuk bersama-sama mengembangkan potensi wisata dan menyediakan pelayanan kegiatan wisata.

Salah satu pelayanan yang penting untuk disediakan adalah sarana dan prasarana, serta organisasi pengelolaan dengan sistem yang jelas. Kondisi eksisting menunjukkan bahwa pelayanan sarana dan prasarana yang disediakan oleh pemerintah saat ini masih sedikit, sehingga perlu adanya penambahan dalam penyediaan sarana dan prasarana untuk mendukung kegiatan pariwisata di Desa Colo. Kekurangan tersebut melatarbelakangi pengelolaan sebagian besar dari fasilitas yang ada dilakukan secara swadaya oleh masyarakat. Hal ini mengindikasikan adanya peran swadaya yang kuat dalam pembangunan suatu aktivitas wisata oleh masyarakat Desa Colo (Muganda,2013).

Pada dasarnya sumber daya manusia di Desa Colo secara kuantitas memiliki tenaga yang cukup untuk melakukan kegiatan pelayanan fasilitas. Di sisi lain, kualitas masyarakat dalam pengelolaan fasilitas wisata di Desa Colo masih terbatas, khususnya dalam upaya mengembangkan asset usaha fasilitas yang mereka miliki saat ini. Hal ini dikarenakan minimnya pengetahuan mengenai pengelolaan wisata, kurangnya pelatihan dan bimbingan yang diberikan oleh pemerintah, serta krativitas dalam pengembangan asset (Mathew and Sreejesh, 2017).

Selain perbaikan kualitas sumber daya manusia (SDM) mengenai pengelolaan fasilitas wisata, masyarakat di Desa Colo juga memiliki hubungan yang kuat antar kelompok wisata dan juga pemuda yang ada di Desa Colo. Hal ini menjadi potensi dari kelompok wisata dalam rangka regenerasi pengelola fasilitas yang dimiliki saat ini, selain itu juga sebagai pendorong pengembangan kelompok menjadi organisasi wisata. Berdasarkan pendapat yang dikemukakan oleh Haryati (2016) menyatakan bahwa partisipasi dari pemuda dalam pengelolaan organisasi wisata merupakan potensi yang besar dalam regenerasi pengelolaan wisata.

Potensi lain yang perlu dikembangkan lebih lanjut adalah harmonisasi hubungan antara pemerintah, pihak swasta, dan masyarakat untuk secara bersama mengembangkan fasilitas wisata yang ada di Desa Colo. Hal ini sebagaimana kondisi yang ada saat ini, di mana dominasi penyediaan masih didominasi oleh pemerintah Kabupaten Kudus, khususnya Dinas Pariwisata, dan Dinas Pekerjaan Umum, serta tentunya masyarakat Desa Colo. Harapannya adalah selanjutnya pemerintah dan masyarakat dapat bekerjasama secara sinergis untuk melakukan bounding (pendekatan mendalam) kepada pihak swasta untuk bersama membangun sarana dan prasarana pendukung kegiatan pariwisata yang ada di Desa Colo.

Tabel 1

Jumlah Fasilitas Wisata di Desa Colo

Deny Aditya Puspasari

Peran Kelompok Usaha Wisata dalam Penyediaan Fasilitas Wisata di Desa Colo, Kabupaten Kudus 


\begin{tabular}{cccc}
\hline \multirow{2}{*}{ No } & \multirow{2}{*}{ Jenis Fasilitas } & \multicolumn{2}{c}{ Jumlah yang Disediakan } \\
\cline { 3 - 4 } & & Pemerintah & Masyarakat \\
\hline 1 & Parkir & 1 (Terminal Wisata) & 9 unit \\
2 & Warung Makan/ Pertokoan & 2 unit & 53 unit \\
3 & Toilet Umum & - & 9 unit \\
4 & Penginapan & 1 & 20 unit \\
5 & Transportasi & 1 jenis (Angkudes) & $1.200($ Ojek) \\
\hline & Total & 2 & 1291 unit \\
\hline
\end{tabular}

Sumber: Pokdarwis Desa Colo, 2018

\section{SIMPULAN}

Pariwisata menjadi salah satu faktor pengembangan ekonomi masyarakat yang paling efektif saat ini. Untuk meningkatkan jumlah pengunjung pada destinasi wisata tertentu perlu adanya fasilitas pendukung sarana dan prasarana yang memadai sehingga bisa menjadi magnet minat pengunjung (Kristin dan Salam, 2016). Dazaya tarik wisata yang beragam di Desa Colo menjadikan Desa Colo menjadi salah satu destinasi yang sering dikunjungi oleh wisatawan saat ini. Hasil penelitian ini menunjukkan bahwa masyarakat memiliki peran yang lebih dominan daripada pemerintah untuk bisa menyediakan fasilitas pendukung wisata secara swadaya dan dengan kondisi SDM yang masih terbatas.

Kualitas SDM yang masih terbatas untuk mengelola fasilitas yang ada di Desa Colo menjadi salah satu kendala yang perludiperbaiki di masa mendatang. Perlunya peningkatan peran pemerintah melalui sinergitas antara pemerintah, pihak swasta dan masyarakat menjadi salah satu kunci untuk bisa meningkatkan kualitas SDM masyarakat, serta meningkatkan pelayanan dalam bidang wisata yang ada di Desa Colo.

\section{SARAN}

Berdasarkan hasil dari identifikasi tersebut, maka untuk meningkatkan kapasitas masyarakat dalam mengelola fasilitas wisata yang dibangun secara swadaya, antara lain:

1. Masyarakat secara berkala dapat melakukan sharing pengalaman dengan

Pokdarwis lain untuk mengetahui manajemen pengelolaan sarana prasarana pariwisata;

2. Perbaikan sarana dan prasarana yang tersedia untuk dapat mengakomodasi jumlah pengunjung yang datang;

3. Perlunya pendampingan secara berkala, yang dilakukan oleh pemerintah dalam keberlanjutan hasil sosialisasi yang telah dilakukan sebelumnya;

4. Meningkatkan hubungan kerjasama yang baik antara pemerintah, pihak swasta, dan masyarakat untuk bersama - sama membangun fasilitas pendukung kegiatan wisata;

5. Secara aktif masyarakat melakukan promosi wisata yang bermanfaat untuk meningkatkan jumlah wisatawan serta menarik pihak swasta untuk dapat membantu dalam mengembangkan wisata tersebut ke depannya.

\section{UCAPAN TERIMAKASIH}

Penelitian ini merupakan bagian dari kolaborasi penulis dengan Pemerintah Kabupaten Kudus khususnya Dinas Pariwisata dan Kebudayaan Kabupaten Kudus dan Pokdarwis di Desa Colo Kabupaten Kudus.

\section{DAFTAR PUSTAKA}

Clare A. Gunn (2002) 'Tourism Planning', 84(3), pp. 670-671.

Ftiyani, L. et al. (2018) 'Analisis Partisipasi Borobudur', Jurnal Mahasiswa 
Jurnal Litbang Provinsi Jawa Tengah, Vol. 19, No. 2, Desember 2021, hal. 115 -121

Administrasi Negara (JMAN),
02(02), pp. 157-169.

Haryati, S. et al. (2016) 'MASYARAKAT DESA ( Studi tentang Pemuda Pengelola Desa Wisata Kandri , Kecamatan Gunungpati , Kota Semarang , Provinsi Jawa Tengah ) Perjalanan bangsa Indonesia tidak lepas', Jurnal Ketahanan Nasional, 22(2), pp. 117-136.

Kristin, R. and Salam, R. (2016) 'Peran Pemerintah Daerah dalam Pengembangan Pariwisata Alam dan Budaya di Kabupaten Tapanuli Utara', JPPUMA: Jurnal Ilmu Pemerintahan dan Sosial Politik UMA (Journal of Governance and Political Social UMA), 4(1), pp. 7996.

Lakshmi, S. R. and Shaji, T. L. (2016) 'Transformation of Coastal Settlements Due to Tourism', Procedia Technology, 24, pp. 16681680. doi: 10.1016/j.protcy.2016.05.188.

Mathew, P. V. and Sreejesh, S. (2017) 'Impact of responsible tourism on destination sustainability and quality of life of community in tourism destinations', Journal of Hospitality and Tourism Management, 31, pp. 83-89. doi: 10.1016/j.jhtm.2016.10.001.

Michael Muganda, A. S. and P. M. E. (2013) 'The Role of Local Communities in Tourism Development: Grassroots Perspectives from Tanzania', kamlaraj, 41 (1), pp. 53-66.

Puspasari, D. A. \& Sariffuddin (2015) 'Peran Gender Dalam Peningkatan Kesejahteraan Masyarakat Desa Wisata Colo Kabupaten Kudus', Tataloka Jurnal, 17, pp. 223-230.

Puspasari, D. A. and Sariffuddin (2015) 'Pengaruh desa wisata colo kabupaten kudus terhadap pertumbuhan permukiman informal di sekitarnya', Prosiding Seminar Nasional Innovation in Environmental Management, pp. VI-5-VI-19.

Raharjana, D. T. (2012) 'Membangun Pariwisata Bersama Rakyat: Kajian Partisipasi Lokal Dalam Membangun Desa Wisata Di Dieng Plateau', Jurnal Kawistara, 2(3), pp. 225-237. doi: 10.22146/kawistara.3935.

Siri, R. and Chantraprayoon, O. S. (2017) 'Local community participatory learning with a nature interpretation system: A case study in Ban Pong, Sansai district, Chiang Mai, Thailand', Kasetsart Journal of Social Sciences, 38(2), pp. 181-185. doi: 10.1016/j.kjss.2016.04.003.

Supriharjo, R. D. et al. (2016) 'Factors Influencing Community-based Heritage Sustainability in Kampung Kemasan, Gresik', Procedia - Social and Behavioral Sciences, 227(November 2015), pp. 498-502. doi: $10.1016 /$ j.sbspro.2016.06.106.

Wijaya, M. I. H., Hutama, S. and ... (2020) 'Peran Kelembagaan dalam Faktor Penarik Pariwisata Kabupaten Temanggung', Bhumiphala ..., 1(November), pp. 27-35. Available at:

https://jurnalbhumiphala.temanggun gkab.go.id/index.php/bhumiphala/ar ticle/view/18.

Yürüdür, E. and Dicle, M. (2011) 'Settlements - Natural environment relationships and tourism potential in Camici (Tokat - Turkey)', Procedia - Social and Behavioral Sciences, 19, pp. 208-215. doi: 10.1016/j.sbspro.2011.05.125. 
